\title{
The rationale for the use of colchicine in COVID-19: comments on the letter by Cumhur Cure $\mathrm{M}$ et al.
}

\author{
Silvia Piantoni ${ }^{1,2}$ (D) Enrico Colombo ${ }^{3} \cdot$ Paolo Airò $^{1} \cdot$ Angela Tincani $^{1,2} \cdot$ Antonio Brucato $^{4} \cdot$ Franco Franceschini $^{1,2}$. $^{1,2}$ \\ Laura Andreoli ${ }^{1,2} \cdot$ Roberto Furloni $^{3} \cdot$ Mirko Scarsi $^{3}$
}

Received: 20 May 2020 / Revised: 20 May 2020 / Accepted: 9 June 2020 / Published online: 20 June 2020

(C) International League of Associations for Rheumatology (ILAR) 2020

\section{Dear Editor,}

We read with great interest the letter by Cumhur Cure $\mathrm{M}$ et al., who raised several points of concern about the use of colchicine for the treatment of severe acute respiratory syndrome coronavirus 2 infection disease (COVID-19) [1]. However, by considering the experience with colchicine in clinical practice and its mechanisms of action, we respectfully disagree with their suggestion of discouraging the use of this drug in COVID-19 [2]. On the contrary, there may be a rationale for investigating its beneficial effects.

Recent observational studies underlined the effectiveness of blocking the COVID-19-mediated cytokine storm by targeting interleukin (IL)-1 and IL-6 in patients with hyperinflammatory syndrome [3]. High-dose intravenous anakinra was used in 29 patients with severe cytokine storm with $89 \%$ of survival rate [4]. One hundred patients with severe COVID-19 pneumonia and acute respiratory failure were treated with tocilizumab, with a rapid and sustained response in $77 \%$ of them [5].

Therefore, the management of COVID-19 should aim at early identification and treatment of hyperinflammation in or-

Roberto Furloni and Mirko Scarsi contributed equally to this work.

Silvia Piantoni

slv.piantoni@gmail.com

1 Rheumatology and Clinical Immunology Unit, Department of Clinical and Experimental Sciences, ASST Spedali Civili and University of Brescia, Piazzale Spedali Civili 1, 25123 Brescia, Italy

2 Department of Clinical and Experimental Sciences, University of Brescia, Brescia, Italy

3 Internal Medicine Department, ASST Valcamonica, Esine, Brescia, Italy

4 Department of Biomedical and Clinical Sciences "Sacco", University of Milano, Ospedale Fatebenefratelli, Milano, Italy der to prevent the cytokine storm. In this view, colchicine may be a drug with potential effects in the early phase of COVID19-mediated inflammation. In fact, colchicine can prevent and treat the flares of many autoinflammatory diseases characterized by aberrant IL-1/IL-6 pathway activation [6]. Notably, colchicine can block the activation of NACHT-LRRPYDcontaining protein 3 (NLRP3) inflammasome, which was demonstrated to be directly induced by the viroporin-E of SARS-CoV [7]. The effectiveness of colchicine has been already reported in COVID-19 patients, even in the presence of hemodynamic complications, such as cardiac tamponade [8], and acute renal injury in a kidney transplant recipient [9].

Besides hyperinflammation, disseminated intravascular coagulation (DIC) and increased occurrence of cardiovascular events are complications of COVID-19 [3, 10]. These might be justified by the presence of endothelial cell infection and endothelitis [11]. Endothelial cell damage can be found also in Behçet's disease (BD), an autoinflammatory disease characterized by neutrophil activation, increased oxidative stress, and generation of a thrombophilic status [12]. Colchicine is largely used in $\mathrm{BD}$, in which it may be useful also for inflammation-induced thrombosis [13]. Furthermore, colchicine was able to reduce the recurrence of secondary cardiovascular events after myocardial infarction, thanks to the inhibition of oxidative stress on the endothelium due to inflammatory cytokines [14]. These studies provide a rationale for a possible role of colchicine in the prevention of coagulation activation and thrombosis in COVID-19.

On the other hand, Cumhur Cure $\mathrm{M}$ et al. hypothesized that colchicine might emphasize SARS-CoV2 infection. This is in contrast with in vitro and animal studies in which colchicinemediated cytoskeleton blockade was able to reduce cell-to-cell transfection during coronavirus infection, thus limiting the viral load [15]. They hypothesized also that colchicine toxic effects might increase the risk of DIC and acute respiratory distress, but in clinical practice this might be relevant only in 
very rare cases of drug hyperdosage, while virus-specific mechanisms are likely to be much more important. Indeed, it should be remarked that, despite its narrow therapeutic window, the risk of serious drug-related toxic effects is minimal for medium-low doses of colchicine $(0.5-1 \mathrm{mg}$ daily) $[9,16]$.

In conclusion, in our opinion, the risk-benefit ratio might be favorable for colchicine as a candidate drug for COVID- 19 . This assumption is supported by different experimental models and extensive clinical experience in autoinflammatory diseases, which did not raise any concern about the safety of this drug. Based on this rationale, several trials are ongoing in different countries to investigate the role of colchicine in the treatment of COVID-19 (Canada [ClinicalTrials.gov Identifier: NCT04322682]; Italy [NCT04375202 and NCT04322565]; Greece [NCT04326790]; Spain [NCT04350320]; Argentina [NCT04328480]; Iran [NCT04360980]; USA [NCT04355143 and NCT04363437]).

The manuscript does not contain clinical studies or patient data.

\section{Compliance with ethical standards}

Disclosures None.

Code availability Not applicable.

Ethics approval Not applicable.

\section{References}

1. Cumhur Cure M, Kucuk A, Cure E (2020) Colchicine may not be effective in COVID-19 infection; it may even be harmful? Clin Rheumatol 39:2101-2102. https://doi.org/10.1007/s10067-02005144-x

2. Piantoni S, Patroni A, Toniati P et al (2020) Why not to use colchicine in COVID-19? An old anti-inflammatory drug for a novel auto-inflammatory disease. Rheumatology. https://doi.org/10. 1093/rheumatology/keaa217

3. Mehta P, McAuley DF, Brown M, On behalf of the HLH Across Speciality Collaboration, UK et al (2020) COVID-19: consider cytokine storm syndromes and immunosuppression. Lancet 395: 1033-1034. https://doi.org/10.1016/S0140-6736(20)30628-0

4. Cavalli G, De Luca G, Campochiaro C et al (2020) Interleukin-1 blockade with high-dose anakinra in patients with COVID-19, acute respiratory distress syndrome, and hyperinflammation: a retrospective cohort study. Lancet Rheumatol 2:e325-e331. https:// doi.org/10.1016/S2665-9913(20)30127-2

5. Toniati P, Piva S, Cattalini M, Garrafa E, Regola F, Castelli F, Franceschini $\mathrm{F}$, Airò $\mathrm{P}$, Bazzani $\mathrm{C}$, Beindorf EA, Berlendis $\mathrm{M}$, Bezzi M, Bossini N, Castellano M, Cattaneo S, Cavazzana I, Contessi GB, Crippa M, Delbarba A, de Peri E, Faletti A, Filippini M, Filippini M, Frassi M, Gaggiotti M, Gorla R, Lanspa
M, Lorenzotti S, Marino R, Maroldi R, Metra M, Matteelli A, Modina D, Moioli G, Montani G, Muiesan ML, Odolini S, Peli E, Pesenti S, Pezzoli MC, Pirola I, Pozzi A, Proto A, Rasulo FA, Renisi G, Ricci C, Rizzoni D, Romanelli G, Rossi M, Salvetti M, Scolari F, Signorini L, Taglietti M, Tomasoni G, Tomasoni LR, Turla $\mathrm{F}$, Valsecchi $\mathrm{A}$, Zani $\mathrm{D}$, Zuccalà $\mathrm{F}$, Zunica $\mathrm{F}$, Focà $\mathrm{E}$, Andreoli L, Latronico N (2020) Tocilizumab for the treatment of severe COVID-19 pneumonia with hyperinflammatory syndrome and acute respiratory failure: a single center study of 100 patients in Brescia, Italy. Autoimmun Rev 19:102568. https://doi.org/10.1016/ j.autrev.2020.102568

6. Leung YY, Hui LLY, Kraus VB (2015) Colchicine-update on mechanism of action and therapeutic uses. Semin Arthritis Rheum 45:341-350

7. Chen IY, Moriyama M, Chang MF, Ichinohe T (2019) Severe acute respiratory syndrome coronavirus viroporin $3 \mathrm{a}$ activates the NLRP3 inflammasome. Front Microbiol 10:50

8. Dabbagh MF, Aurora L, D'Souza P et al (2020) Cardiac tamponade secondary to COVID-19. JACC Case Rep. https://doi.org/10.1016/ j.jaccas.2020.04.009

9. Gandolfini I, Delsante M, Fiaccadori E, Zaza G, Manenti L, Degli Antoni A, Peruzzi L, Riella LV, Cravedi P, Maggiore U (2020) COVID-19 in kidney transplant recipients. Am J Transplant. https://doi.org/10.1111/ajt.15891

10. Kuba K, Imai Y, Rao S, Gao H, Guo F, Guan B, Huan Y, Yang P, Zhang Y, Deng W, Bao L, Zhang B, Liu G, Wang Z, Chappell M, Liu Y, Zheng D, Leibbrandt A, Wada T, Slutsky AS, Liu D, Qin C, Jiang C, Penninger JM (2005) A crucial role of angiotensin converting enzyme 2 (ACE2) in SARS coronavirus-induced lung injury. Nat Med 11(8):875-879

11. Varga Z, Flammer AJ, Steiger P, Haberecker M, Andermatt R, Zinkernagel AS, Mehra MR, Schuepbach RA, Ruschitzka F, Moch H (2020) Endothelial cell infection and endothelitis in COVID-19. Lancet 395(10234):1417-1418

12. Becatti M, Emmi G, Silvestri E, Bruschi G, Ciucciarelli L, Squatrito D, Vaglio A, Taddei N, Abbate R, Emmi L, Goldoni M, Fiorillo C, Prisco D (2016) Neutrophil activation promotes fibrinogen oxidation and thrombus formation in Behçet disease. Circulation 133(3): 302-311

13. Nonaka D, Takase H, Machii M, Ohno K (2020) Colchicine therapy for deep vein thrombosis in a patient with vascular-type Behçet disease: a case report. Medicine (Baltimore) 99(16):e19814

14. Tardif JC, Kouz S, Waters DD, Bertrand OF, Diaz R, Maggioni AP, Pinto FJ, Ibrahim R, Gamra H, Kiwan GS, Berry C, López-Sendón J, Ostadal P, Koenig W, Angoulvant D, Grégoire JC, Lavoie MA, Dubé MP, Rhainds D, Provencher M, Blondeau L, Orfanos A, L'Allier PL, Guertin MC, Roubille F (2019) Efficacy and safety of low-dose colchicine after myocardial infarction. N Engl J Med 381(26):2497-2505

15. Milewska A, Nowak P, Owczarek K et al (2018) Entry of human coronavirus NL63 into the cell. J Virol 92(3):e01933-17

16. Stewart S, Yang KCK, Atkins K, Dalbeth N, Robinson PC (2020) Adverse events during oral colchicine use: a systematic review and meta-analysis of randomised controlled trials. Arthritis Res Ther 22(1):28

Publisher's note Springer Nature remains neutral with regard to jurisdictional claims in published maps and institutional affiliations. 